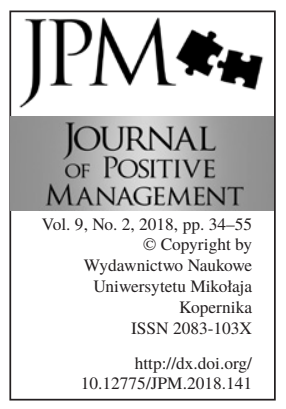

\title{
THE EFFECTIVENESS OF THE POLISH SPORT FEDERATIONS IN ATHLETES' OPINION
}

\author{
Aleksandra Leśniewska ${ }^{\mathrm{a}}$,Aneta Stosik ${ }^{\mathrm{b}}$, Gabriel Łasiński $^{\mathrm{c}}$ \\ a,b,c University School of Physical Education in Wroclaw, Wrocław, \\ Poland \\ ae-mail: aleksandra.lesniewska@awf.wroc.pl \\ be-mail: aneta.stosik@awf.wroc.pl \\ ce-mail: gabriel.lasinski@awf.wroc.pl
}

\begin{abstract}
Purpose: The main aim of this work was to evaluate the effectiveness of how Polish Sport Federations (PSF) function in the opinion of athletes who represent the country in various sporting disciplines. The following research questions were posed: in what way do PSFs support athletes representing the country in selected sporting disciplines? Do members of national teams have an influence on the activity of PSFs and what is their satisfaction in that matter?

Methodology: The research consisted of two parts: individual in-depth interviews $(\mathrm{N}=10)$ and a diagnostic survey based on a questionnaire study $(\mathrm{N}=102)$. The research included athletes in both individual and team Olympic sporting disciplines.

Findings: PSFs strive to support their athletes mainly in terms of providing them with sport equipment, organizing and coordinating competitions and training camps, as well as health care, however the low level of engagement of PSFs was noted in marketing and providing information, as well as in financial support for athletes. Athletes declared high expectations regarding the transparency of their federations as well as better decision-making and access to information

Implications: Polish Olympic athletes expect from the PSFs that represent them an approach based on partnership as well as consideration of their strategic position as a group of key stakeholders. PSFs thus seem to face a serious challenge to transform their approach in how they relate and communicate with their key stakeholders and to recognize that it is essential to ensure their satisfaction with their cooperation.
\end{abstract}

Keywords: effectiveness, national sport federations, stakeholders, sport athletes, good governance

Paper type: Research paper

\section{Introduction}

Due to numerous scandals in international and local sport associations (e.g. corruption, lack of transparency, sustainability problems etc.), there is a rise of public attention towards those entities. A strong position of traditional sport organizations is now being questioned and it is justified to investigate who those 
organizations serve to. Therefore, the main purpose of the study is to evaluate how effective Polish Sport Federations are in the opinion of sports athletes. The key issues considered in the study are: functioning of those organizations from the athletes' perspective, identifying their main concerns and describing the relation between them and their Federations.

In order to make sure that Sport Federations fulfil their obligations in a way that they ought to, their actions and interests need to be recalibrated with the normative expectations of their social constituency of legitimation (Geeraert, 2015). Referring to organizational effectiveness, several different approaches have been analyzed e.g. goal-oriented approach, process approach, system resources oriented approach or competing values model. In our opinion the most relevant theory for this study is the strategic stakeholder approach (Cameron, 1984). It highlights that organizations operate in a complex environment and its stakeholders (employees, managers, shareholders or partners) may have different goals. Therefore, the effective organization is the one that meets possibly the broadest expectations of its main stakeholders.

While analyzing the Sports Federations it seems natural that the needs of athletes should be seriously taken into consideration. However different studies show (e.g. Papadimitriou, Taylor, 2000) that athletes are one of the least satisfied groups. The Principal-Agent theory could be useful to explain this phenomenon (Geeraert, 2015). Although athletes are not direct principals of National Federations, they are the main reason for those organizations to exist. Serving athletes is the basic argument for social legitimization of those entities. Athletes are linked to National Federations through a long chain of delegation, which increases an agency slack (Nielson and Tierney, 2003). That puts them in a situation where there is no control mechanisms and as the Principal-Agent model predicts - this causes the effect that agent minimizes his efforts on behalf of the principal and even pursue its own interests at the expense of the principal (Pollack, 2003). Mere consultation offers no assurance that athletes' concerns and ideas will actually be taken into consideration; this requires access to decisionmaking and decision-making power (Young, 2000).

\section{Organisational effectiveness - essence and evaluation}

Effectiveness is a concept which is ambiguous and subject to various interpretations. This is a result of various types of organizations, the peculiarities of their operations and the conditions they operate in, and consequently the goals that motivate them.

The goals of an organization may be oriented toward economic, organisational, social or personal questions. The various interests, needs, values or demands in an organisation mean that there is no single method for evaluating their effectiveness (Cameron, 1984; Slack, 1997). This intra-organisational diversity results in the

THE EFFECTIVENESS OF THE POLISH SPORT

Aleksandra Leśniewska Aneta Stosik Gabriel Łasiński 
THE EFFECTIVENESS OF THE POLISH SPORT

Aleksandra Leśniewska Aneta Stosik

Gabriel Łasiński category of effectiveness being truly "paradoxical" (Cameron, 1986), and the approach to evaluating it must take into account the relations between these paradoxical criteria. As a result, certain criteria must be adopted which are particular for and important to a specific organisation and groups of stakeholders. The measure of effectiveness thereby is multi-dimensional - financial and nonfinancial, marketing and social, objective and subjective (Kaplan and Norton, 1992; Neely et al., 2002).

The diversity of opinions regarding organisational effectiveness has led to the rise in management science of several different conceptions of effectiveness and methods of evaluating it. Cameron (1984) provides a comprehensive overview of several concepts of how to evaluate organisational effectiveness:

\section{Goal-attainment approach}

An organisation is seen as effective is it achieves its goals. The popularity of this approach in professional sporting organisations and the area of competitive sport, among others, was shown by Slack (1997), where evaluation of the achievement of goals leads to the analysis of data regarding points, rankings, and victories. This method is useful when the goals are clearly defined, measurable, and in a fixed period of time. In the case of diverse and diffuse goals, they cannot be identified, and consequently comparative analysis is required.

\section{Systems resource approach}

This is based on open systems theory. In order to obtain resources, organisations form relationships with their environment based on the exchange of goods and services. Yuchtman and Seashore (1967) define organisational effectiveness in categories of its bargaining position, which is reflected in 'the ability of the organisation in either absolute or relative terms to exploit its environment in the acquisition of scarce and valued resources'. The concept of 'bargaining position' implies a rejection of any kind of specific goal (or function) as the final criterion for the effectiveness of an organisation. Instead of this, the object of interest should be the more general potential of an organisation understood as a system acquiring resources. This method is used in organisations that do not have guaranteed resources from their surroundings. It may be used to compare organisations that have different goals. Its weakness and limitation is that for example, a professional sporting club could be evaluated as effective without having any competitive advantage (in results) (Cameron, 1980).

\section{Internal-Process Approach}

From this perspective, an effective organisation is one in which technological and communications processes function smoothly without unnecessary internal tensions, conflicts and tie-ups. The method is oriented mainly toward human 
resources. A process or vertical system of management assessment is featured in this approach. (Cameron, 1980). The work process and group tasks or the common zones are associated with the principle of added value in the process chain. This requires clear definition of the supplier - internal client - external client relationships.

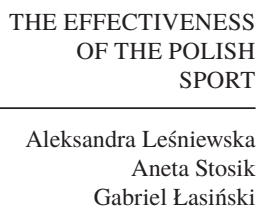

\section{Strategic constituencies approach}

Counted among holistic methods, this approach is growing in popularity. In this approach oriented toward strategic constituencies, it is emphasized that an organisation operates in a complicated environment, in which shareholders, stockholders, and partners (external constituencies) as well as managers and employees (internal constituencies) have different expectations in regard to the organisation (different goals). The degree to which an organisation meets the goals and expectations of particular constituencies determines its effectiveness. In this method, measures of effectiveness can ultimately satisfy the expectations of stakeholders (Connoly et al., 1980). Robbins' (1990) work also emerges from this approach.

\section{Competing Values Model}

The beginning for the rise of this model was a list of 39 indicators of effectiveness, created by Campbell et al. (1974). This list was then analyzed by Quinn and Rohrbaugh (1983) with a view toward organizing the indicators into groups. These were then subjected to statistical analysis and to main dimensions were obtained, which would allow all the indicators to be divided into four main groups or areas. The first dimension groups criteria of effectiveness that highlight flexibility, autonomy, and dynamism at one pole, and at the other criteria emphasizing permanence, order, and control. This means, that some organisations can be seen as effective if they change, adapt, and are relatively informal. Others, in contrast, can be seen as effective if they are stable, predictable, and have a permanent structure - for example, most universities and state institutions. The second dimension contrasts criteria of effectiveness that place an emphasis on internal affairs, integration and unity to those that have to do with orientation toward the position in the environment, differentiation and rivalry. These two dimensions make it possible to divide the criteria into four areas of competing values:

- orientation toward people and internal processes -human relations model,

- orientation toward adaptation and seeking resources - open systems model,

- orientation toward achieving goals, maximizing results (profit) - rational goals model,

- orientation toward consolidation, knowledge management, communication, control and process quality - internal process model. 
THE EFFECTIVENESS OF THE POLISH SPORT

Aleksandra Leśniewska Aneta Stosik

Gabriel Łasiński
Having indicated these four different models, which are sets of four areas of generating criteria for evaluating effectiveness - it is indicated that there is no single universal measure to evaluate it (Quinn, 1988).

These concepts presented by Cameron should be supplemented by two more contemporary methods that are regarded as part of the holistic school in management studies. The first is the balanced scorecard by Kaplan and Norton (1992). This considers four perspectives for evaluating effectiveness: the financial, the client's, that of internal processes and of development. Evaluation is made on the basis of quantitative and qualitative measures always selected in regard to the peculiarities and needs of an organisation. The method is quite widespread and is respected in management science and in business practice.

The second of these methods is the Performance Prism, developed by Neely et al. (2002). In the evaluation of effectiveness, this method also considers four dimensions: stakeholder satisfaction, strategy, processes, and potential. The main assumption of the Performance Prism is an organisation concentrating on satisfying the needs of its stakeholders. These then determine the strategy, processes and direction in which an organisation develops.

\section{A concept of evaluating the effectiveness of the operation of Polish Sport Federations}

On the basis of characteristics of global concepts for evaluating the effectiveness of an organisation in management studies it was concluded that for the evaluation of the operation of PSFs, the strategic constituencies method would be appropriate. Important for the selection of this method was the nature of the organisation studied (non-profit) as well as the special role of stakeholders in its proper operation. It was concluded that sportspeople constitute the target group of stakeholders, and the level of their satisfaction with the meeting of their needs will explain the evaluation of the effectiveness of the operation of PSFs. This is in accordance with the view of De La Luz Fernandez-Alles and Llamas-Sanchez (2008) that in the case of non-profit organisations, the question of acceptance of an external system of evaluation their effectiveness is at times fundamental for their survival. Significant also in the final selection of a method were contemporary trends toward a holistic approach in the evaluation of organisational effectiveness, in particular the role of the needs (satisfaction) of stakeholders.

In this research project, it was decided to focus on the opinions of athletes representing Poland in Olympic disciplines as a target group of stakeholders. It was assumed that researching opinions regarding the operation of Federations would include the following areas of mutual relations: communication, financial and organisational support, decision-making, promotion of the discipline and of sport, as well as event planning. Next, every area was assigned evaluation criteria. Take in Table 1. 
Financial and organizational support

$\checkmark$ Stipends,clothing, provision of equipment,

$\checkmark$ insurance, indemnities

$\checkmark$ Excursions, training camps, recreations, treatment

$\checkmark$ Awards, prizes

$\checkmark$ Advising

\begin{tabular}{|ll|}
\hline \multicolumn{2}{l}{ Decision-making } \\
$\checkmark$ & Participation in decision-making \\
$\checkmark$ & Participation in governing bodies \\
\hline
\end{tabular}

Promotion of the discipline and of sport

$\checkmark$ Advertising and PR

$\checkmark$ Participation in international committees and structures

$\checkmark$ Promotion in the media

The proposed areas and effectiveness criteria are complementary and are presented with no intentional order. Verification of the level of satisfaction of athletes as well as researching the opinions of key clients of Polish Sport Federations is a pioneering attempt to evaluate the effectiveness of the operation of these institutions in Poland.

\section{Research Methodology}

The aim of the research was to evaluate the effectiveness of the operation of Polish Sport Federations (PSFs) in the opinions of athletes who represent the country in Olympic sporting disciplines. The following research questions were posed: In what way do PSFs support athletes representing the country in selected sporting disciplines? What kind of support do they not provide athletes associated with Polish Sport Federations? Do members of national teams have an influence on the activity of Sport Federations in Poland? How do Polish sportspeople evaluate their cooperation with PSFs? How satisfied are Polish sportspeople with the activities of PSFs?

\subsection{Method}

In order to answer the research questions posed in this work, the method of a diagnostic survey was used - in-depth interviews as well as a questionnaire given to a selected group of sportspeople competing at the national team level in individual and team Olympic disciplines.

Selection for the research sample with whom interviews were conducted was targeted in nature and was directed toward athletes at the highest level of sporting achievement - team members representing Poland in well-known and popular Olympic disciplines (volleyball, basketball, athletics) The basis for the selection of such criteria was the belief that known athletes in popular (also in the media) sporting disciplines are a key group of stakeholders, whose
Table 1.

Areas and

effectiveness criteria

for the operation of

PSFs in the opinions of stakeholders.

Source: Own elaboration. 
THE EFFECTIVENESS OF THE POLISH SPORT

Aleksandra Leśniewska Aneta Stosik

Gabriel Łasiński opinion regarding cooperation with PSFs would be diagnostic, transparent, and representative. In the study, 14 in-depth interviews were conducted with wellknown (and visible in the media) national team members in Poland. On the other hand, in the questionnaire survey 102 sportspeople took part, also in Olympic disciplines, selected randomly, ranging in age from 18 to 40 years $(x=26)$, of whom $41 \%$ were women and $59 \%$ men. Among the respondents, $71 \%$ of those studied were individuals who were still professionally active and in the course of their athletic career. Athletes were from both individual and team Olympic disciplines (including ice hockey, field hockey, athletics, shooting, basketball and handball). The questionnaire contained 25 closed and open questions regarding four thematic areas (areas for evaluating the effectiveness of PSFs). The following evaluation areas were highlighted: communication with PSFs, organisational and financial support, participation in decision-making, promotion of athletes and sport disciplines and planning/organization of sporting events, competitions, training camps and travels. The questionnaire and the interviews were conducted between April and July 2016. For the sake of logic and consistency, the results from both methods applied are presented together.

It should also be pointed out to some limitations of the adopted research methodology. Qualitative research requires from the researcher to be an observing subject and it is limited to his abilities as an observer. However, despite of the lack of standardized tools in the field of qualitative research, they may provide a better understanding of phenomena or deepen knowledge. Comparing the results obtained among other entities is limited and it is difficult to generalize the results. However, the authors' intention is to make comparative research based on the adopted research approach, in subsequent time intervals, using the adopted methodology mainly for descriptive, explanatory and exploratory purposes with the intention of measuring attitudes and opinions of the respondents in the field of sport organizations not well recognized in the literature.

\section{Discussion}

\section{Better athletes - have it better}

Analysis of the results of ethnographic and questionnaire research showed that in terms of ensuring basic care and creating the conditions for training and competing Polish sport federations were positively assessed by Polish team members. Athletes appreciate the quality of sports equipment on which they train, the number of training camps and the service at competitions. Those surveyed also evaluated "financial and organisational support" on the part of the Federations like, for example, starting fees, subsidies for transportation to competitions and training camps, or subsidies for sports equipment as satisfactory; however, they rated relatively low the direct financial support in the form of the payment of 
bonuses for results, sport stipends or scholarships or awards - in each of these categories, over $80 \%$ of those surveyed expressed their dissatisfaction. Take in Figure 1.

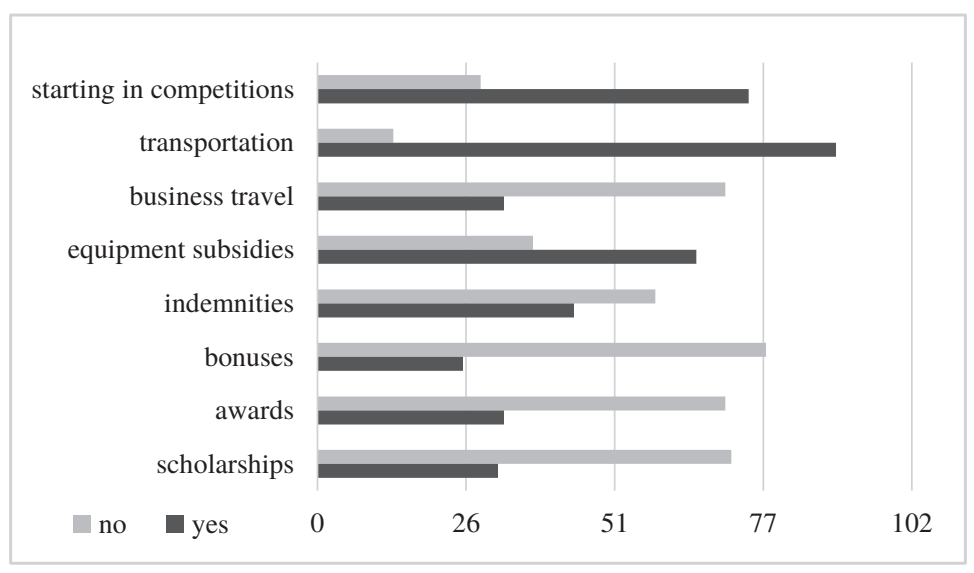

In the evaluation, the general level of satisfaction among sportspeople with organisational and financial support was noted as astonishingly low - only $13 \%$ of team members evaluated the activities of the Federations positively, but as many as $27 \%$ of sportspeople were unsatisfied and $20 \%$ very unsatisfied.

The range of non-financial support from Polish Federations was evaluated through such facts as purchase of equipment and sport clothing for athletes, health insurance and payment of coasts from treatment that may arise, as well as organisational and logistic assistance in case of injury, organisation of trips to training camps, provision of professional specialist assistance (psychologists, physiotherapists, coaches), support in the area of nutrition and supplementation after training and starting in competitions, offering the chance to regenerate the body (spa, biological renewal, wellness, etc.), as well as recreation. Most of those questioned confirmed that they had received that type of assistance from Polish Sport Federations. Take in Figure 2.

Rather characteristic results appeared also for the question regarding the type of support provided by PSFs in the area of the two-track career of athletes. It turns out that Polish athletes rate the assistance of PSFs as extremely low in organisational issues related to studies or work ( $80 \%$ negative responses) or legal support or during transfers or financial negotiations (93\% negative responses). The only aspect of the participation of PSFs that was positively assessed was in the organizing and conducting training camps and entering into competitions (84\%), as well as training and sporting development (66\%). The opinions presented, however, apply mainly to athletes at the highest levels of achievement:
THE EFFECTIVENESS OF THE POLISH SPORT

Aleksandra Leśniewska Aneta Stosik Gabriel Łasiński

Figure 1. Financial support from Polish Sport

Federations in athletes' opinions.

Source: Own elaboration based on the data obtained in the study. 
THE EFFECTIVENESS

OF THE POLISH

SPORT

Aleksandra Leśniewska

Aneta Stosik

Gabriel Lasiński

Figure 2.

Non-financial support from PSFs in athletes' opinions.

Source: Own

elaboration based on the data obtained in the study.

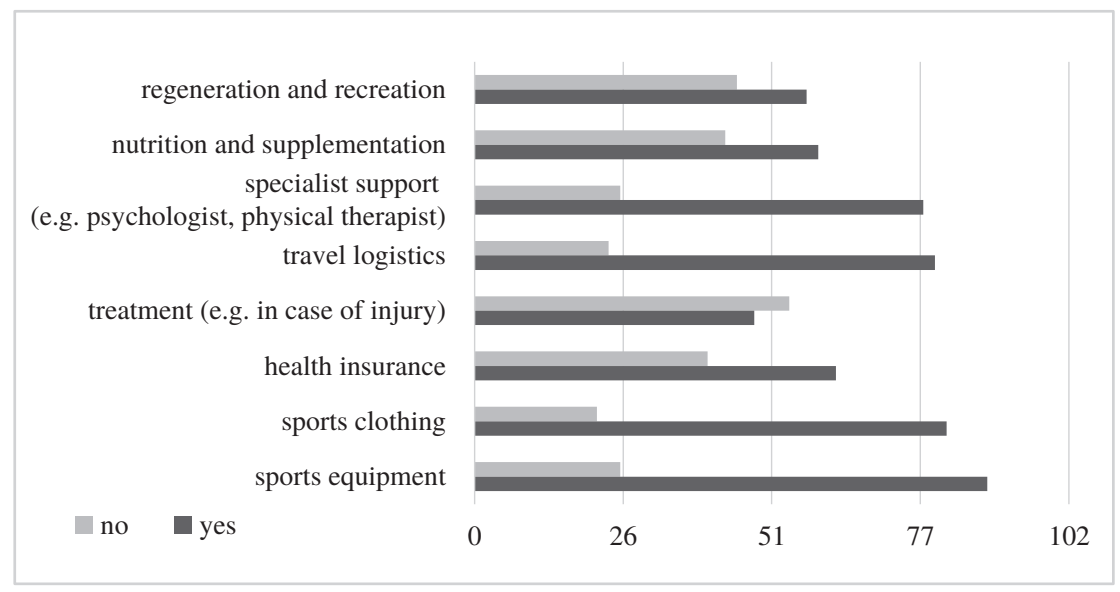

From the very beginning when I was on the team, I was always surrounded by special care (...) because I showed talent in this sporting discipline ... and the federation was really keen on my competing at the highest international level, and so I had everything I needed (Interview, April 2016).

High-level athletes are additionally supported financially by a system of sport scholarships, which are distributed at the level of the Ministry of Sport and Tourism. These depend exclusively on the results from the previous season, and the Sport Federations have no influence on who receives them. It is precisely a lack of means for living expenses or a reduced number of training camps abroad that athletes with a lower level of achievement complain about.

The number of training camp days is determined by the Ministry of Sport in coordination with the Polish federation in the given discipline on the basis of the results that an athlete has achieved in the past few years. Meaning, the better I was, the more days I can use, and that is a simple principle. Of course, there are some exceptions in the case of athletes who show good prospects for a given year and hadn't been able to show off their ability in previous years, but that's rare (Interview, June 2016).

The pool of money assigned for athlete instruction also comes from the Ministry of Sport and Tourism, which in the case of vast majority of sport federations is the entire budget that an organisation has at its disposal. In other words, the well-being of the athletes does not only depend on the federation for a given discipline and how it takes care of athletes, but also on centrally-made decisions. The interlocutors emphasized that the amount of money allocated 
from the state budget is growing, and so the overall training conditions are very good. However, quite apparent from the respondents' statements how small their participation in the operation of PSFs is and how distinct, even entirely different the realities are in which athletes and officials operate.

(...) sometimes it happens that there are two parallel institutions, creations: the federation as an office and operation, and then there's us. And we have a lot fewer ... rights, (...) there is some regulation or another (...) and usually it's for the benefit of the federation more than it is for us, (Interview, May 2016).

Athletes, when asked about details of their cooperation with PSFs, answered with a certain scepticism and conservativism, as well as a passive attitude testifies to their perception of their position in the structure of PSFs as a subordinate one. In the world of sport, the conviction is widespread that athletes should not be interested in federation matters, despite the fact that they are the main beneficiaries of these organisations.

The organisation of the Polish Federation is not always at a high level. It's hard for me to talk about this, and I'd rather ... even though I'll be made anonymous, I'd really rather not get into it too deeply (Interview, April 2016).

[...] pretty much we have no influence on anything. They give us lots of things, but it's kind of along the lines of we're giving you things and be glad you have them, but it's not like we can discuss, for example, about which company we'd like to have equipment from, or which nutritional products. I mean, they choose equipment from the company which the president represents that year, because they ${ }^{*}$ represent two sporting goods companies $X$ in Poland [...] Although, we can't complain, because they're top-class global companies, and so thanks to that we have world-class equipment, but we have no influence over what we receive (Interview, June 2016).

The above statement shows not only the "gilded cage" that the highest-level national athletes are kept, but it also describes the president's conflict of interest, which is legally prohibited by an amendment to the Act on Sport from July 2015, but it also unmasks why isolating athletes from any organisational decisionmaking whatsoever might be profitable for officials.

* When necessary, the form "they" will be used to better preserve confidentiality and anonymity.
THE EFFECTIVENESS OF THE POLISH SPORT

Aleksandra Leśniewska Aneta Stosik Gabriel Łasiński 
THE EFFECTIVENESS OF THE POLISH SPORT

Aleksandra Leśniewska Aneta Stosik

Gabriel Łasiński

\section{On the official discourse and its consequences}

In Poland the discourse in force is that an athlete is to focus exclusively on training and not be interested in the activities of the Federation, and many athletes share that view:

the boss ... the vice president of the federation told me this: I'm not telling you anything on purpose, because an athlete should think about how to shoot best, you should have what you need most and shouldn't bother with the rest of the stuff, because that doesn't do ... any good anyway, and well, looking back, I think that was really right, because getting so deep into what's going on in the office doesn't make any sense at all, because it takes your attention away from what's most important, because each one of us has something to do, right? Athletes should work on, work on training, so they can achieve the best results, and the federation should ensure them that, and so that's the role of each one, so somebody getting involved in someone else's territory ... well, that might not end so well (Interview, April 2016).

As athletes, we know what we're supposed to do and we don't get involved, even if we can sometimes see that it isn't as good as it should be, we don't get involved in what people do who have more power than we do, we are only workers who are employed there and do it sometimes maybe more out of ideology and the desire to achieve something, who have set goals in life as athletes, and not for any material benefits. And so we sometimes turn a blind eye to ... certain things. Because everyone knows ... every time you play on the national team it's a great thing, and sometimes you just have to get over it (Interview, May 2016).

In fact, athletes competing at a high level are occupied with their sporting duties, and so they entirely cede the field of working on federation matters to officials. A consequence of this approach is, however, that they automatically lose the ability to exert any influence on officials, their bargaining position weakens and instead of stepping up as the most important group of stakeholders, thanks to whom they could legitimise the organisation, they give up on governing and control, and slide over into the position of supplicants.

A rather disturbing phenomenon is the complacency of athletes that results from the fear of losing their status as team members. One of the respondents who has repeatedly represented Poland in one of the most popular disciplines in the country - in their description of their relationship with the federation, used the word worker, who is easy to replace. Athletes, considering how important representing the country is to them, often enough accept the low quality of the work of the federation and do not comment on it publicly. This is particularly the case in the case of team sports, in which team member rotation is natural and 
easier to justify than in the case of individual sports. The influence of officials on the team line-up can be a tool for manipulation.

When it comes to qualifying for championship events, always (...) the final decision is made by the administration. Even if every demand has been met, the decision of the board may be not to go to such an event. And that decision can be made for various reasons (Interview, June 2016).

There were some athletes who qualified for a very prestigious competition, that they should have been sent to, but instead the federation decided differently for its own reasons of its own. I think that's not OK, because you don't enter, train and qualify only not to be sent after qualifying. The coaches intervened, themselves feeling aggrieved, but nothing came of it though (...) because the final decision had been made, period (Interview, April 2016).

Officials exploiting their position is an extraordinarily negative phenomenon, which often has a negative influence on athletes. Such activities would appear to be rather common in sport, although some federations are trying to make the criteria for making personnel decisions more transparent. Another symptom of the weak position of athletes in the federations is the way in which sportspeople are treated when they suffer a long-term injury.

Most of all, we expect some kind of support, not only ... when everything works out and is going well, but also (...) when difficult situations arise, (...) some unfortunate accident, that is when an athlete needs the most support (Interview, April 2016).

When I was injured, well, I heard that I no longer had the support of the federation, because ... (I was receiving money from another source - ed.) and so I did not need personnel support anymore [...], that was the pretext they used. The truth was that I had been injured and it was not known if I would return, and so it didn't make sense to waste money. When after the injury I was honoured with a World Cup win, well, then the phone call came, asking if I needed anything. And so... well, unfortunately, that how it is. It's really sad (Interview, May 2016).

Polish Sport Federations, in the interlocutors' opinions, take care of their members as long as they are in excellent shape, but also excellent health. Unfortunately, athletes' experiences show that in case of injury they cannot count on the support, loyalty, or long-term cooperation "for better or for worse." Moreover, medical exams seem to be needed solely in order to obtain a doctor's 
THE EFFECTIVENESS OF THE POLISH SPORT

Aleksandra Leśniewska Aneta Stosik

Gabriel Lasiński

Figure 3.

Influence of Polish athletes on decisionmaking in PSFs in selected areas of federation activity.

Source: Own elaboration based on the data obtained in the study. opinion permitting an athlete to enter competitions, and not to care for their general health over many years.

Theoretically we have medical exams in the main sports medicine centre twice a year, but (...) I don't know if that is sufficient. Well, a lot of things look that way, I won't name names, but I know cases of athletes who had some small problem detected, but nothing more came of it, and well, it didn't end up so well later (Interview, June 2016).

The situations described by respondents raise the question: are such actions ethical? What is the real cost of athletes achieving excellent results? A good athlete does not seem to be the main goal of the sports federations, but rather the athlete is a tool for generating results, for which the federation receives the funding which supports the entire organisation.

The above statements confirm the survey results, which show that respondents assessed their decision-making ability working with PSFs as extremely low. Over $90 \%$ of athletes believe that they do not have the ability to participate in decisions about the election of federation board members, and decisions are made without consulting athletes regarding financial issues, changes in the rules and regulations, or even the calendar of events and training camps. Take in Figure 3.

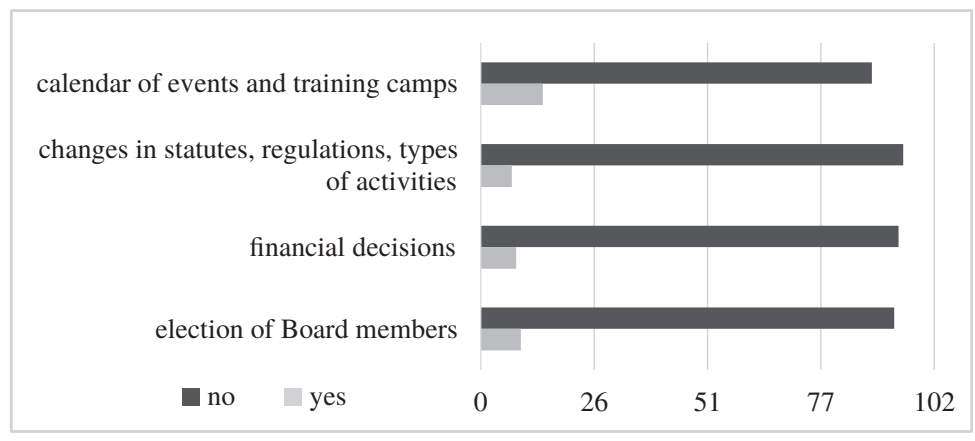

Similar results take shape in the area of the opportunity for athletes to sit on various types of commissions or committees - the overwhelming majority of respondents (93\%) claim that they have no opportunity to sit on governing bodies, although at the same time they do not declare a desire to do so (only $16 \%$ expressed such a desire). The clear majority of respondents feel the need to create a position of spokesperson who would represent their interests in PSFs (80\%). The overall level of satisfaction in the area of "decision-making of athletes within PSF 
structures" is presented in chart 7 . Evaluating this category positively was only $8 \%$ of members. Take in Figure 4.

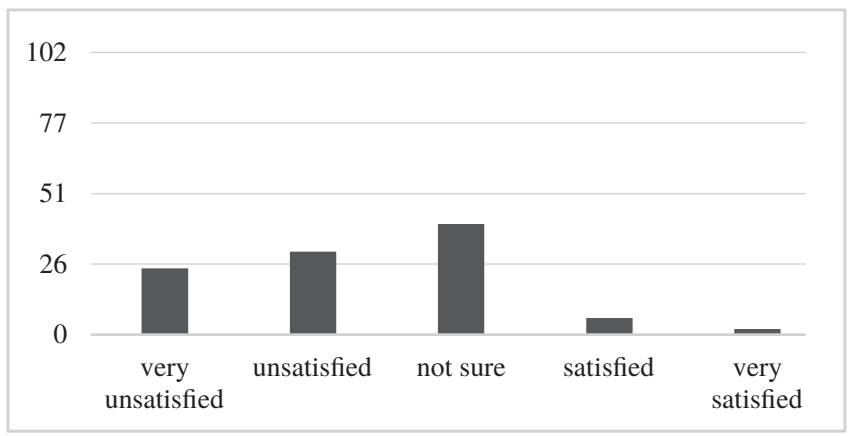

Figure 4.

Evaluation of the level of athlete satisfaction in the category participation in decision-making

Source: Own elaboration based on the data obtained in the study.

\section{Communicating or informing?}

Communication between a federation and its athletes is as a rule one-way and highly selective. Sportspeople claim that they do not receive much information regarding the activity of the federations.

I think I don't know anything on this topic. Sometimes I would like to know what is going on in the federation, but we're just not allowed into that, and that's like, normal, it seems to me (Interview, April 2016).

Access to financial reports, probably no one has that, because coaches, coaches often ask, "alright, what's our budget?" There is no answer, we don't know what budget we have (...) we don't know, and coaches don't know (Interview, June 2016).

The majority of respondents (76\%) acknowledged that Polish Sport Federations communicate with them through various channels, of which the most frequently used channel is electronic, especially e-mail, instant messaging, social media (72\%), directly in conversations with representatives of the Federation (50\%), or through the traditional postal service (26\%). Following up on this response, respondents were asked about their level of knowledge regarding important aspects of the operation of Polish Sport Federations. The results showed declared knowledge of the organisational structure of the institutions analyzed at $63 \%$, of the strategies, goals, plans and direction at $43 \%$, decisions and planned changes at $36 \%$. These results indicate that as many as $2 / 3$ of those studied are not informed about the activities of their Sport Federation, and over half are not aware of the details. Respondents, who declared that they had knowledge in these areas, most 
THE EFFECTIVENESS OF THE POLISH SPORT

Aleksandra Leśniewska Aneta Stosik

Gabriel Lasiński

\section{Figure 5.}

Evaluation of the level of satisfaction in the category

communication with PSFS

Source: Own

elaboration based on the data obtained in the study. frequently obtained this by reading the content posted on federation webpages $(80 \%)$ on social media $(39 \%)$, or in newsletters $(28 \%)$. Characteristic for the responses seems to be a lack of direct communication or a very low frequency of it. Thus the fact should not surprise that in the summary of this category of communication with Polish Sport Federations, only one in four is satisfied. Take in Figure 5.

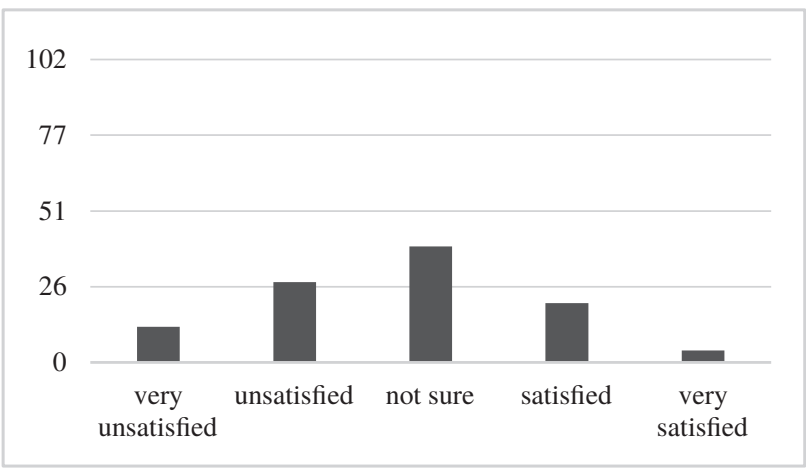

Athletes do not have access to federation plans, are not informed about elections or the programs of candidates, nor about key decisions - even those that affect them directly are made without consultation.

And such things like decisions about where training camp will be, who the team coach will be -athletes have no voice in this, the instruction section takes care of that, in which there are experts (...) who should know what they're doing, it isn't always that way, but in fact the voice of athletes isn't really taken into account (Interview, May 2016).

With the Polish Federation X, there's no negotiating. And even if (...), something is important to us (...), because we've earned it through our hard work, or our results ... there's no conversation, there's no way of coming to a common understanding, only that what they impose on us we have to accept. If we don't, well, it's ... it's thanks for everything, then (Interview, June 2016).

As the respondents claim, in PSFs do not consider athletes' opinions in matters that are not essential for them, while in minor matters, or in obvious cases requiring consultation, such as the type of outfit and equipment, sportspeople are sometimes asked their opinions, although this is not the standard everywhere. In some federations, some small changes are taking place, and the organisations are 
declaring their openness to comments and consultations, but actual practice shows that these are merely declarations.

They impose their thoughts, and the athlete has to comply, etc. But it isn't like they put up the plan and that's it, not at all, you can talk with them, you can negotiate. I won't hide that those negotiations sometimes end with 'OK, we'll think about it, we'll let you know' and nothing changes (...) then really after a week or two, it turns out that things are just how they wanted (Interview, April 2016).

These statements demonstrate that the position of team-members is not strong in PSFs, although it should be noted that some federations stand out with their more contemporary approach in this area. There are a few examples, and the range of change is small, but one can view such examples optimistically as previews of wider changes in the mentality of these organisations.

\section{Lack of transparency and the proliferation of unnecessary positions}

As mentioned above, athletes do not know much about the activities of their sports federations, despite the fact that they themselves do not obtain such information they also believe that it is very difficult to access. They learn about central decisions or elections to the board through informal channels, whereas official communication is incidental They acknowledge that the activities of the federations is not transparent.

Although full transparency when it comes to the finances of the federation would be really necessary. [...] For example, there is no information about who, when and where goes to training camps abroad [...] Probably if I were to write to the federation asking who when where for what training camp, I would get that information. But it seems to me that such information should be open to public opinion, because it's no secret. And showing it with 100\% transparency they would nip all speculation in the bud (Interview, April 2016).

The lack of transparency in the operations of the federations is especially apparent in the area of hiring new employees in the office, as well as in the coaching staff for national teams. According to athletes, the criteria for appointing someone to the position of coach is not clear and understandable in all federations. In this area, the personal preferences and affinities of the presidents or also the head of training still play too great a role.

Regarding the appointment of coaches, that's the great mystery, the key to who is chosen and where some appear, while others disappear, that is the highly 
THE EFFECTIVENESS OF THE POLISH SPORT

Aleksandra Leśniewska Aneta Stosik

Gabriel Łasiński emotional approach of the head of training, some old connections. For us, the word "connections" means a lot (Interview, May 2016).

The competition for coach - the best one doesn't only win, only the one who, ... is just ... more ... favoured, with whom someone had reached an agreement (Interview, May 2016).

It should be added that the practices described above are not the rule in all federations. However, sportspeople believe that successes in a given sporting discipline do not always result in improvement of the conditions for the athlete or in the development of the discipline.

For sure, my federation is an inflated federation if it comes to the number of people employed. Even though we are one of the largest federations in the country, for sure it could be reduced, because I think in just the accounting department there are seven ladies employed, and that's got to be excessive (Interview, April 2016).

I'll say this, this federation worked better 10 years ago, maybe better than now, in terms of organisation, and there were 2-3 fewer people employed. [...] Instead, I think that they go in and loaf about. We once had one office, now we have two. And there just a bunch of people in both offices, whereas we have let's say one sponsor more, but what do we have to show for that? Nothing, really. (...) Maybe what's it's about is that the office would have it better. (...) That so many people would go to world championships, to any championship, that's never happened (Interview, June 2016).

The employment of additional people in PSF administration is fairly negatively viewed by athletes, especially in situations when their qualifications are in doubt, and their duties and effectiveness are unclear.

(...) I think that if there are competitions and the bosses go, they should rather work on making ties with sponsors, making new contacts, but to do so you have to speak another language, and that's a problem (Interview, June 2016).

There are many examples, when there's an attractive trip abroad, at often enough there are as many officials as there are athletes. Let's say for the Olympics for example. If we look at the makeup of the delegation, there are probably as many people or more accompanying the team as there are athletes. The same goes for gear, because all of those officials get the same Olympic gear as the athletes do, and that costs a lot (Interview, June 2016). 
According to athletes, the federations and the Polish Olympic Committee are treated by some people as a "travel agency". They emphasize that in these organisations there is no clear division of labour, and there are too many social functions and positions handed out on a discretionary basis.

The most diverse in terms of the evaluation in the studied categories, however, are the promotional and marketing activities of the PSFs. Those surveyed were asked whether in their opinion Polish Federations make marketing efforts to promote their sporting discipline. $42 \%$ answered in the affirmative (definitely true, $9 \%$, somewhat true, $33 \%$ ), and regarding the main forms of promotion, they listed webpages $(82 \%)$, social media $(69 \%)$, traditional media $(45 \%)$, traditional advertising (39\%). The variety of answers in the studied group may result from the diverse participation of respondents in various sporting disciplines, both individual and team sports, as well as more or less popularized ones.

When athletes were asked if they perceive the presence of officials representing their Federation in the media, the majority answered in the affirmative $35 \%$ somewhat true, $11 \%$ definitely true). They rated as surprisingly low their level of overall satisfaction with their cooperation with PSFs in the category "promotion of athletes and the sporting discipline". As many as $56 \%$ of team members are unsatisfied or very unsatisfied with the promotional activities of Polish Federations, and nearly $1 / 3$ of those studied have no opinion in this matter. Take in Figure 6.

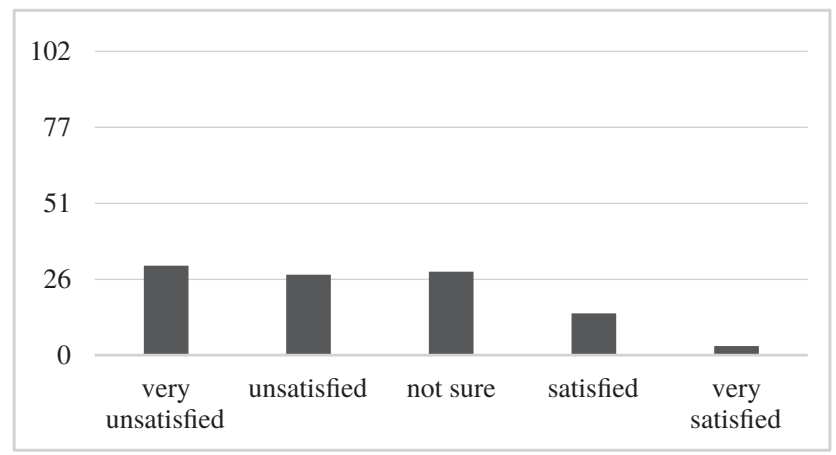

\section{Athletes' prescriptions for remedying the situation}

Polish team members perceive a limitation of the operation of Polish Sport Federations, but often also see various possibilities for improving this state of affairs. When asked about these possibilities, they indicated, among other things, the necessity of forming a athletes' commission authorized to make decisions.

$$
\text { If we had our own athletes' representative in the federation, the flow of }
$$

THE EFFECTIVENESS OF THE POLISH SPORT

Aleksandra Leśniewska Aneta Stosik Gabriel Łasiński

Figure 6. Level of athletes' satisfaction in the category promotion of athletes and the sporting discipline

Source: Own elaboration based on the data obtained in the study. 
THE EFFECTIVENESS OF THE POLISH SPORT

Aleksandra Leśniewska Aneta Stosik

Gabriel Łasiński information and what is going on in the federation, we would have much more information, and I think that the cooperation would then be even better (Interview, April 2016).

It would certainly be useful if in every federation there was an athletes' commission, like there is in the Olympic Committee. Maybe we don't have any governing power, and so that the members of the athletes' commission would have some voice in the Polish X Federation. And then the committee chairs could be on the board, that's one. And two, to have a vote in elections, just like district federations, clubs have (Interview, May 2016).

Sportspeople perceive many benefits from forming a group of athletes representing the interests of all athletes associated with federations, benefits many having to do with improving communication between athletes and officials as well as in increase in their decision-making powers. The duties of such representatives could be assumed by retired athletes, who after the end of their career would have time to participate in board meetings and to offer their opinions in the decisionmaking process, and at the same time would understand the athletes' position. Key, however, in the respondents' opinion would that such a representative would be elected by the athletes themselves.

Among the other issues raised by athletes, postulates about greater transparency in activities in all areas stood out, including the issue of making objective and transparent the criteria for selection to travel to key competitions as well as the staffing of important positions, liberalisation of the terms of hiring people to work, clear definition of the tasks and duties of all positions, evaluation based on the effects of work and a proper and fair division of power and decisionmaking:

I have never had any problems with the federation, and so here I really cannot say a bad thing, but I do think that everything could be much more transparent, clear, and then there wouldn't be such questions (Interview, May 2016).

Above all, there has to be rotation of people, there has to be some kind of competition for positions, whether for that of president, or the head of training, or of coach, because... if there isn't a sense of competition, and connections decide everything, then well, generally everybody more or less ... can easily ... violate the boundaries of that position, and abuse their position. And that's a problem (Interview, May 2016).

Athletes also perceive the need for better use of the marketing potential by the federations. 
Athletes still aren't fully used by the federation as the federation would be able to, and that's a problem of the federation, for sure. We sign a contract with the federation and declare that the federation has complete rights to use our image in the Polish Team uniform, and they can really sell those and make some money. They could use athletes during various events for children and youth for promoting the discipline. That could really be developed more, but it's going in the right direction (Interview, June 2016).

Despite the isolation of athletes from organisational matters, they are well aware of areas that need improvement and of their own need to strengthen their position in the national structures of sport federations.

\section{Conclusion}

From the in-depth analysis of the research results it should be stated that Polish Sport Federations try to support their athletes with financial and organisational assistance (mainly in terms of equipment and sporting competitions) as well as with training camps and health care. Despite the declared initiatives of the Federations in the area of marketing support as well as providing information and the ability of athletes to make decisions, the opinions of the respondents indicate a low level of engagement of the Polish Federations in these areas. Generally, poorly evaluated was support for athletes by PSFs. Some more highly appreciated initiatives of the Sport Federations would be promotion of the discipline and athletes in their sports career development as well as better communication through various channels as well as a higher level of engagement in providing information about matters important to athletes, or in other words a more transparent way of communicating about the activities of the Polish Federations. Sportspeople for the most part poorly rated their ability to influence key decisions for them in the area of the calendar of events and training camps, the distribution of finances, election of representatives to the boards of Federations or changes regarding the statutory activities of the Federations.

The current approach to building advantage in the area of organisation and achieving above-average effectiveness demands deep cooperation both between organisations as well as within an organisation. The researched market of the cooperation of sportspeople with the Polish Sport Federations does not appear to be following the way of partnership-based relationships with their main stakeholders. In spite of evident changes in the commercial organisations market in the direction of increasing value for stakeholders through creative ways of building relationships and trust, in PSFs such changes cannot be detected. The main clients of these organisations - athletes - do not seem to be active participants in the exchange of value or co-creators of ways of acting in the mutual interest of all. They are only beneficiaries of the basic functions and constitute 
THE EFFECTIVENESS OF THE POLISH SPORT

Aleksandra Leśniewska Aneta Stosik

Gabriel Łasiński a source of earning benefits more for the organisation than for themselves. They constitute rather an unequal partner in the market for sports services.

According to the trend of positive management, the respondents' expectations correspond with selected areas, such as: positive practices in human resource management, positive leadership, a positive perspective on the analysis of organizational problems and positive organizational practices. This new point of view also introduces a different perception of the relationship between the organization (PSF) and the client (player). On the basis of a positive management approach, research results indicate expectations towards:

- conscious influence of activities on other members of the organization,

- relational transparency,

- high standards of cooperation,

- sustainable integration towards the qualitative cooperation of cooperating entities.

In this context, it is also important to understand the positive relationship between trainers and the organization of PSF, which should be based on kindness, strengthening of trust, willingness to cooperate, with mutual involvement as a necessary condition for achieving a higher level of organizational efficiency.

Contemporary and modern organisations increasingly regard their clients as partners in business and seek such market solutions that both sides of the market game achieve a win-win result. Currently, in the opinion of their key stakeholders, PSFs see the result of this game entirely differently. It seems in the face of this study that athletes, as the main partners of sport federations, merely constitute a means for generating benefits for the organisation. In the light of contemporary theories of management, especially in the context of resource theory, "development of proper relations is in these times an essential condition of effective activity on the market and the creation of value" (Kwiecien, 2014), therefore transformation of the Polish Sport Federations approach to relationships and communication with their key clients, namely athletes seems to be a serious challenge to take up.

To improve the efficiency of PSF actions, the authors recommend greater promotion of open communication - partnership based on dialogue and discussion, aimed at obtaining feedback, increasing the involvement of athletes in decision-making processes and in result increasing their sense of influence and co-responsibility.

\section{References}

Cameron, K.S. (1984), "The effectiveness of ineffectiveness", in: Staw, B.M., Cummings, L.L. (Eds.), Research in organizational behaviour, Vol. 6, pp. 235-285.

Cameron, K.S. (1986), "Effectiveness as paradox: Consensus and conflict in conceptions of organizational effectiveness", Management Science, Vol. 32 No. 5, pp. 539-553. 
Connolly, T., Conlon, E.J., Deutsch, S.J. (1980), ”Organizational effectiveness: A multiple constituency approach", Academy of Management Review, Vol. 5 No. 2, pp. 211-217.

De la Luz Fernández-Alles, M., Llamas-Sánchez, R. (2008), "The neoinstitutional analysis of change in public services", Journal of Change Management, Vol. 8, No. 1, pp. 3-20.

Eisenhardt, K. (1989), "Agency theory: An assessment and review", Academy of Management Review, Vol. 14 No. 1, pp. 57-74.

Geeraert, A. (2015), Sport Governance Observer 2015. The legitimacy crises in international sports governance, Play the Game, Copenhagen.

Henri, J.F. (2004), "Performance measurement and organizational effectiveness: Bridging the gap", Managerial Finance, Vol. 30 No. 6, pp. 93-123. DOI: 10.1108/0307 4350410769137

Kaplan, R.S., Norton D.P. (2005), 'The balanced Scorecard- Measures that drive performance", Harvard Business Review, July-August, pp. 71-79, available at: https://hbr. org/2005/07/the-balanced-scorecard-measures-that-drive-performance (accessed 19 August 2016).

Kaplan, R.S., Norton, D.P. (2007), "Using the balanced scorecard as a strategic management system", Harvard Business Review, July-August, available at: https://hbr. org/2007/07/using-the-balanced-scorecard-as-a-strategic-management-system (accessed 12 May 2016).

Kwiecień, A. (2014), "Effectiveness of Relations as a Condition for Success of Contemporary Enterprises", Studia Ekonomiczne. Zeszyty Naukowe Uniwersytetu Ekonomicznego w Katowicach, No. 202, pp. 56-64.

Neely, A.D., Adams, C., Kennerly, M. (2002), The Performance Prism: The Scorecard for Measuring and Managing Stakeholder Relationships, Financial Times Series, Prentice Hall, London.

Nielson, D.L., Tierney, M.J. (2003), ”Delegation to international organizations: agency theory and World Bank environmental reform", International Organization, Vol. 57 No. 2, pp. 241-276.

Papadimitriou, D., Taylor, P. (2000), "Organizational effectiveness of Hellenic national sports organizations: A multiple constituency approach", Sport Management Review, Vol. 3 No. 1, pp. 23-46.

Pollack, M.A. (2003), The engines of European integration. Delegation, Agency and Agenda setting in the EU, Oxford University Press, Oxford.

Quinn, R.E. (1988), Beyond Rational Management, Jossey-Bass, San Francisco.

Quinn, R.E., Rohrbaugh J. (1981), ”A Competing values approach to organizational effectiveness”, Public Productivity Review, Vol. 5 No. 2, pp. 122-140.

Robbins, S.P. (1990), Organization Theory. Structure, Design and Applications, Prentice Hall, Englewood Cliffs, New Jersey.

Slack, T. (1997), Understanding Sport Organization. The Application of Organization Theory, Human Kinetics, Champaign.

Young, I. (2000), Inclusion and democracy, Oxford University Press, Oxford.

Yuchtman, E., Seashore, S.E. (1967), "A system Resource approach to organizational effectiveness”, American Sociological Review, Vol. 32 No. 6, pp. 891-903. 